\title{
Visualization of ATP dynamics during mouse exercise
}

\author{
Masamichi Yamamoto \\ 京都大学大学院医学研究科腎蔵内科, ₹ 606-8507 京都市左京区聖護院川原町54 (Department of Nephrology, Kyoto Uni- \\ versity Graduate School of Medicine, 54 Shogoin-Kawahara-cho, Sakyo-ku, Kyoto 606-8507, Japan)
}

Received: May 14, 2019 / Accepted: June 26, 2019

\begin{abstract}
Muscle contraction requires energy. However, the dynamics of adenosine triphosphate (ATP) in the skeletal muscle contraction in vivo is unknown. Therefore, we tried to visualize ATP dynamics in mice. By performing various gene modifications using Goateam reported as FRET-type fluorescent protein that senses ATP, we succeeded in creating a mouse that can visualize ATP level in the cytoplasm. By resting the skeletal muscle of this mouse from contraction exercise, it succeeded in capturing in vivo the decrease in the amount of ATP by exercise and the recovery of the amount of ATP by rest. This mouse can be used to evaluate muscle movement in vivo by ATP dynamics.
\end{abstract}

Jpn J Phys Fitness Sports Med, 68(4): 245-249 (2019)

Keywords : ATP, dynamics, intravital, muscle contraction, visualization

\section{緒言}

骨格筋運動とATP 筋肉の収縮運動は, ミクロレベルで はアクチンーミオシンの滑り運動により引き起こされる. この力学的反応の前には(1)活動電位によるチャネルの開 口，(2)カルシウム流入による筋小胞体からのカルシウム 放出，(3カルシウムとトロポニンートロポミオシン複合 体の形成，(4)アクチンのミオシン結合部位が露出，(5) ATPの加水分解によるエネルギーを利用したミオシン 頭部の屈曲運動の 5 つの連続した化学的反応が起こる. つまり, ATPの加水分解は力学的反応の直前に位置す る化学的反応である ${ }^{1-4)}$. しかし, 細胞レベルおよび臟器 レベルでは，収縮運動時のATP動態は全く不明である。 近年, MRIの発達により骨格筋内のクレアチンリン酸動 態が報告され，間接的にATP 動態を推測できるように なった，その結果，クレアチンリン酸は運動直後にリン 酸基を ADP 受け渡し, クレアチンに変化するため低 下し，休息数分後に回復してくると報告された ${ }^{5)}$. しか しながら，ATPが同様の挙動を取るのかは以前不明な ままである。

\section{方 法}

マウスの構築と飼育 すべての実験手順は群馬大学大学 院医学研究科, 京都大学大学院医学研究科の委員会に よって承認された実験における動物の世話および使用の
ためのガイドラインに従って行われている.

ATP 感受性のFRET 型蛍光タンパク質 Goateam ${ }^{6}$ が 発現する構築を大阪大学免疫学フロンティア研究セン ターの星野および改正によって提供されたR26-CAGべ クターやCTVベクター (Addgene プラスミド\#11739) を用いて行った，上記構築を FuGeneHDやエレクトロ ポレーション法を用いて ES 細胞 ${ }^{7)}$ に導入した。 ES ローンは，サザンブロット法により確認した。プローブ は星野および改正によって提供された。 また，PCR，お

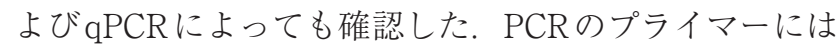
P1 5'-AGAGCCTCTGCTAACCATGTTCATGCCTTC およびP2 5'-GTGACACTAAGTCAAACGCGAAA を用いた。 Goateam 挿入遺伝子は342-bp断片として 増幅された。 qPCR反応は, Kusabira Orange用のプ ライマー5'-AGAGATGACACTACGCGTCACAA, 5'-GTGACACTAAGTCAAACGCGAAA，およびTaqMan プローブ5'-CCGAGGGCGGGCCAATGCを用いて 行った. プライマー5'-TGCCAAGTATGATGACATCAAGAAG および5’-GGTCCTCAGTGTAGCCCAAGAT，ならびにTaqMan プローブ5'-TGGTGAAGCAGGCATCTGAGGGCを用いて内部対照配列 Gapdh を増幅 した.

上記で選択されたクローンを ICR $\times$ ICR マウスの桑実 胚期胚 (SLC, 静岡, 日本) と凝集させ, キメラを作製した。 各 ES クローン由来の雄性キメラを C $57 \mathrm{BL} / 6 \mathrm{~J}$ 雌と交配 
させ，へテロ接合F1子孫（C57BL/6J x 129バックグラ ウンド）を得た。

\section{骨格筋運動の観察}

臟器の生体内イメージング

マウスに麻酔 (イソフルラン, 人工呼吸器を使って 1.5\%〜2.0\%）をかけた後に, 脚の毛を剃り, 脚から皮膚 を剥ぎ取った，蛍光を検出するために，脚部を特注の拘 束具に固定し，ステージヒーター（東海ヒット）を使用 して温めた。露出した前脛骨筋（TA）をPLAN APO 1.0 ×対物レンズ（Leica）を備えた立体顕微鏡（M165FC; Leica）を用いて観察した。筋収縮は坐骨神経の電気刺激 $(20 \mathrm{~Hz})$ によって誘発した。

画像解析 Kusabira Orange と EGFP蛍光の画像は MetaMorphソフトゥェア（Molecular Devices）を用い て作成した。 タイムラプスシリーズのXYドリフトを排 除するために, ImageJのStackReg プラグインを使用し た. EGFP と Kusabira Orangeの蛍光強度を測定するた めに, MetaMorph とImageJを使用した。

\section{結果}

マウス生体内でのATP 動態の可視化 骨格筋運動時の ATP 動態を調べるには，ATP量を感受するFRET型夕 ンパク質の Ateamを利用する事が最有力候補であった $(\text { Fig. 1 })^{8)}$. そこで, Ateamでも pHにより安定で, 原理 的に組織深部まで計測する事が可能な新規 ATP 感受セ ンサーGoateamを用いて検討する事にした。

培養細胞株を用いた研究から, FRET型タンパク質は 十分な輝度值が得られなければFRET 現象を捉える事 ができない事が報告されている，そこで，Goateamの十 分な輝度值を得るため, マウス生体内でGoateamを過 剩発現させる戦略を取る事にした。プロモーター $C M V$, $E F 1 \alpha, C A G, P G K, M C 1, \beta$-actin, またはUbCの制 御下にGoateamを結合させて，S 40 polyA をその直下 に結合させたプラスミドをFuGENE HDを用いてES細 胞ヘトランスフェクションして, 合計で105クローンの 安定発現株を得た。各ES細胞クローンから RNAを抽 出し, cDNAを合成した後に内在の Gapdhと㨂入され たGoateam プローブの発現量をTaqMan PCR 法を用 いて検討を行った。 (分子) Goateamプローブ/(分母) Gapdhを行う事で細胞数の補正を行った上での各クロー ンでATPプローブの発現量を比較した。 その結果, ES 細胞内で発現量が714倍差のクローンを得られているこ とが確認できた（Fig. 2).

この中から, 発現量が多いもの6クローン（714倍, 151倍, 80 倍, 77 倍, 56 倍, 45倍) と発現量が中くらいのも の12クローン（32 倍, 26倍, 25倍, 24倍, 20倍, 17倍, 14倍,
13 倍, 12 倍, 12 倍, 11 倍, 11 倍), 発現量が少ないもの 8 クローン（ 5 倍, 3 倍, 3 倍, 2 倍, 2 倍, 1 倍, 1 倍, 1 倍) の合計 25 クローンからアグリゲーション法にてマウスを 作成した。

$50 \%$ 100\%キメリズムのマウスが得られ，F1が得ら れた20クローンは，尾から得たゲノムを用いてPCR法 でATPセンサーの有無を確認した．5クローン（714倍, 151倍, 80倍, 77倍, 45倍) はF1を得る事ができなかった。 F1が得られた20クローンに対して, 肝臓でのATPセン サーによる蛍光を 2 光子顕微鏡にて調べたが, ほとんど 蛍光は得られなかった。また, 肝臓に直接 ATP 合成を 阻害する薬剤（2-deoxy glucose とOlygomycinA）を添 加したが, ATP量の低下を蛍光比として捉える事がで きなかった

これより，発現量が多いと個体として致死または遺伝 子のサイレンシングが起こる可能性が推測された。 また, 発現量が少ないと蛍光や ATP 量変化による蛍光変化を 捉える事ができないと推測された。

そこで, 導入する遺伝子領域・コピー数・プロモーター を制御する事にした，導入する領域はサイレンシングが 起こりにくい領域として知られるマウスRosa26領域を 選択した. コピー数は 1 コピーから検討し, プロモーター は前述 7 種類に加えてマウスRosa26 の内在性プロモー ターも検討した。 その結果, $C A G$ プロモーター制御下で 1 コピー導入したマウスでGoateamの十分な輝度值を得 ることに成功した。これより, 細胞質内でGoateamが発 現する事で細胞質内の ATP 量を計測する事ができるマ ウス個体が作出できた。

骨格筋運動時のATP 動態 次に, 骨格筋運動時のATP 動態を計測できるかを検討した，蛍光顕微鏡下で骨格筋 運動を観察するため, マウスにイソフルラン麻酔を施す 事で顕微鏡下に固定し, 坐骨神経に直接電気刺激した時 に収縮運動が起こる前頸骨筋を高速で撮影した。その結 果, 電気刺激による筋肉の収縮運動と共に前頸骨筋の ATP量低下が観察された (Fig. 3)。また, 電気刺激中 (30 秒）は前頸骨筋のATP量低下が持続した，更に，電気刺 激を終えた後には前頸骨筋の ATP量が回復傾向を示し, 約 3 分後には収縮運動前と同様まで回復する事が捉えら れた (Fig. 3)。この結果は, 骨格筋細胞質内に単独で存 在するATPが骨格筋の収縮運動により消費された事を 示唆している. また, 骨格筋収縮運動の停止により, 骨 格筋細胞質内に単独で存在するATP は回復してくる事 を示唆している.

\section{考察}

骨格筋運動にはエネルギーが必要で, アクチンーミオ シンの滑り運動時のATP加水分解反応にともなうミオ 


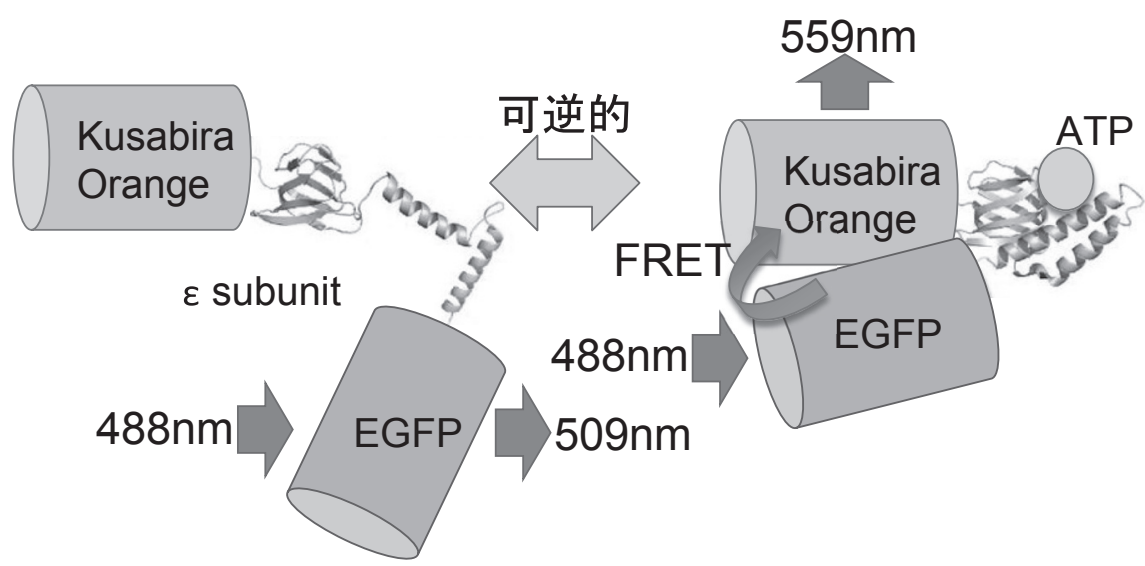

Fig. 1 Schematic drawing of Goateam probe Variants of GFP (cp173-mEGFP) and OFP $(\mathrm{mKO} \kappa)$ were connected by the $\varepsilon$ subunit of Bacilus subtilis $\mathrm{F}_{0} \mathrm{~F}_{1}-\mathrm{ATP}$ synthase. When ATP is free (left), $\varepsilon$ subunit is extended, then separates the 2 fluorescent proteins, resulting in low FRET efficiency. When ATP is binding (right), $\varepsilon$ subunit breaks, then brings the 2 fluorescent proteins closer together, resulting in increasing FRET efficiency.

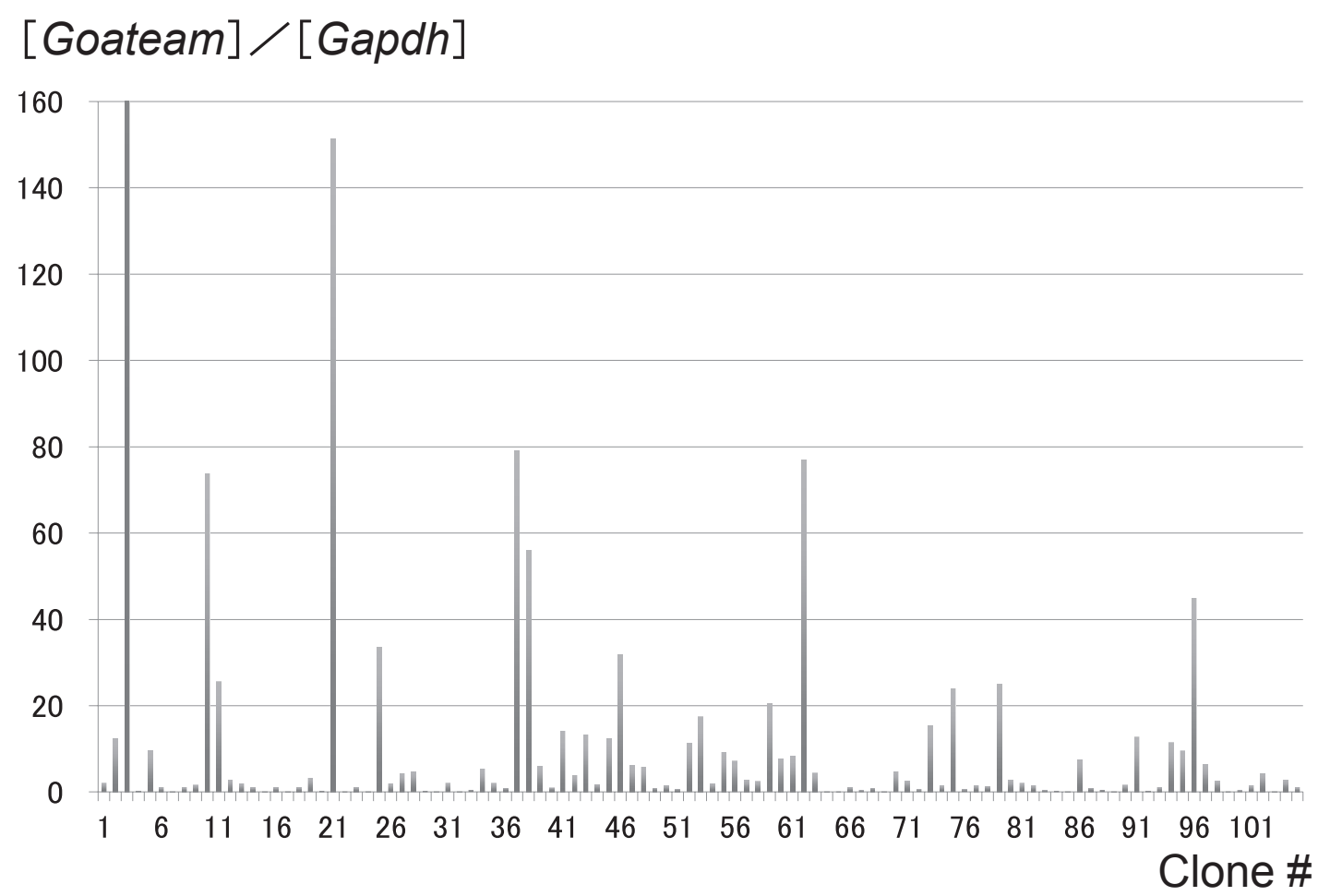

Fig. 2 Ateam expression level in ES cell clones

A bar graph showing the expression level of Ateam in 105 ES cell clones (horizontal axis) compared with \# 54 clone.

シン動態はこれまで非常に良く調べられ推測されてきて いた。 今回, 世界で初めてマウス個体内の骨格筋運動時 に扔けるATP動態が明らかとなった。

筋収縮時における白筋と赤筋のATP 動態 骨格筋は収 縮速度の遅いI 型線維と, 収縮速度が早く収縮力の強い
II型線維に大別できる. 更にII型は有酸素的能力の高い IIA 型線維と有酸素的解糖能力の低い IIB 型線維に分け られる。 I 型線維とIIA 型線維ではミトコンドリア密度 と活性が高い。一方，IIB型線維ではミトコンドリア密 度と活性が低く, 酸素非依存的な解糖系が中心に働いて いる.しかし, 各細胞種の実際のATP動態は不明である。 

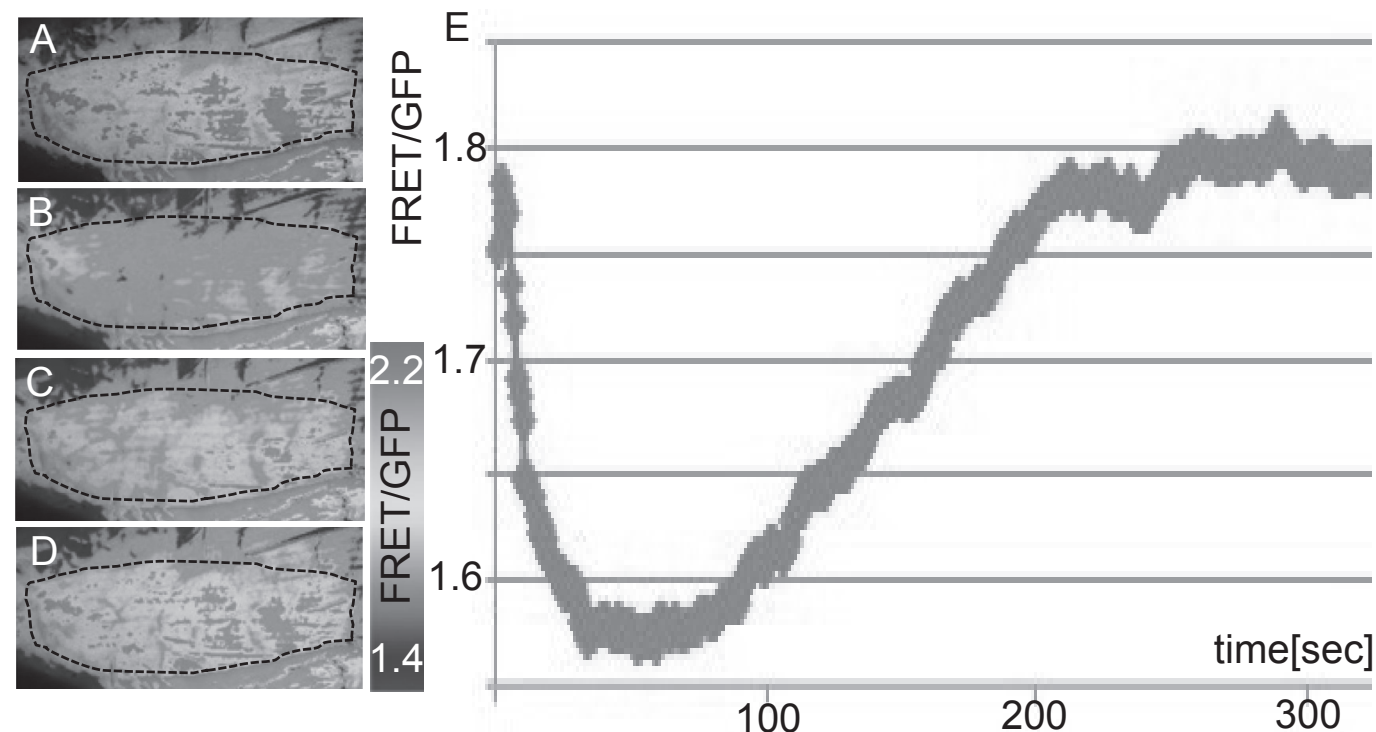

Fig. 3 ATP Dynamics in ATP Visualization Mice' Muscles

Intravital imaging of FRET/GFP ratios of the tibialis anterior muscle subjected to stimulation $(20 \mathrm{~Hz})$ of the sciatic nerve $(\mathrm{A}-\mathrm{E})$. The anterior tibialis muscle was observed for 10 seconds $(\mathrm{A})$ and then stimulated at $20 \mathrm{~Hz}$ for 30 seconds (B). Then, after stopping stimulation, images were recorded for 270 seconds (C: 120 seconds later, D: 270 seconds later). Graph E shows change of the FRET / GFP ratio of anterior tibialis muscle before and after electrical stimulation.

今回のATP 可視化マウスは細胞レベルでのATP 動態を 生体内で調べる事ができる。また，各細胞種はミトコン ドリア密度の違いから含有するNADH量が異なるため, SHGにより非侵襲的に区別する事が可能である ${ }^{9)}$.この 技術を用いれば，マウス個体内で収縮する各骨格筋細胞 種の機能を様々な負荷強度と時間軸で生体内エネルギー の側面から詳細に調べる事ができるようになる。

高強度運動中の筋疲労へのATP 量低下の役割 全身運 動中の筋疲労には細胞のATP 供給が寄与している可能 性が示唆されている。具体的には，ミオシンATPase機 能の障害の原因としてATP量が低下し，ミオシンに即 時結合するATPが少なくなる事による効率の低下が示 されている ${ }^{10)}$ 。また, SERCA 機能の障害としては，筋 肉の弛緩を遅らせる事が示唆されている. 更に筋細胞膜 の $\mathrm{Na}^{+} / \mathrm{K}^{+}$ATPase ポンプ機能の障害として, 線維の興 奮性抄よび機能を変化させ，筋疲労を助長する可能性が ある。これまで私達の研究で長時間の筋収縮運動により ATP量回復能の低下が観察できてきている，また, 神経 細胞内の ATP 量が $\mathrm{Na}^{+} / \mathrm{K}^{+}$ATPase ポンプ活性を調節し ている結果が得られている。これょり, 骨格筋でも同様 の機能を担っている可能性があり, 筋疲労助長に関与し ていると推測される。従って, ATP可視化マウスはサプ リメントや食品成分による疲労回復効果を検証する新し いッールになる可能性がある.

\section{謝 辞}

本研究を遂行するにあたり, 群馬大学の和泉孝志先生, 京都大学の柳田素子先生および研究室の方々, 京都大学の 今村博臣先生, Nestle Institute of Health Sciences の坂本啓 先生, 名古屋工業大学の小笠原理紀先生に多大な協力をし て頂きました。また, 新学術領域「細胞コミュニティー」と 科学技術振興機構さきがけに研究費をサポートして頂きま した。この場をお借りして感謝申し上げます。

\section{利益相反自己申告 :}

本研究において, 著者に利益相反はない.

\section{引用文献}

1) Yanagida $T$, Iwaki M, Ishii $Y$. Single molecule measurements and molecular motors. Philos Trans $R$ Soc Lond B Biol Sci 363: 2123-2134, 2008.

2) Spudich JA, Sivaramakrishnan S. Myosin VI: an innovative motor that challenged the swinging lever arm hypothesis. Nat Rev Mol Cell Biol 11: 128-137, 2010.

3) Sweeney HL, Houdusse A. Myosin VI rewrites the rules for myosin motors. Cell 141: 573-582, 2010.

4) Lymn RW, Taylor EW. Mechanism of adenosine triphosphate hydrolysis by actomyosin. Biochemistry 10 : 4617-4624, 1971.

5) Haris M, Singh A, Cai K, Kogan F, McGarvey J, Debrosse C, Zsido GA, Witschey WR, Koomalsingh K, Pilla JJ, Chirinos JA, Ferrari VA, Gorman JH, Hariharan H, Gorman RC, Reddy R. A technique for in vivo mapping of myocardial creatine kinase 
metabolism. Nat Med 20: 209-214, 2014.

6) Nakano M, Imamura $\mathrm{H}$, Nagai $T$, Noji H. $\mathrm{Ca}^{2+}$ regulation of mitochondrial ATP synthesis visualized at the single cell level. ACS Chem Biol 6: 709-715, 2011.

7) George SH, Gertsenstein M, Vintersten K, KoretsSmith E, Murphy J, Stevens ME, Haigh JJ, Nagy A. Developmental and adult phenotyping directly from mutant embryonic stem cells. Proc Natl Acad Sci US A 104: 4455-4460, 2007.

8) Imamura $H$, Nhat $K P$, Togawa $H$, Saito $K$, Iino $R, K a-$ to-Yamada Y, Nagai T, Noji H. Visualization of ATP levels inside single living cells with fluorescence reso- nance energy transfer-based genetically encoded indicators. Proc Natl Acad Sci U S A 106: 15651-15656, 2009.

9) Konagaya Y, Terai K, Hirao Y, Takakura K, Imajo M, Kamioka Y, Sasaoka N, Kakizuka A, Sumiyama K, Asano T, Matsuda M. A Highly Sensitive FRET Biosensor for AMPK Exhibits Heterogeneous AMPK Responses among Cells and Organs. Cell Rep 21: 26282638, 2017.

10) Fujii T, Namba K. Structure of actomyosin rigour complex at $5.2 \AA$ resolution and insights into the ATPase cycle mechanism. Nat Commun 8: 13969, 2017. 